\title{
Simulation of Nitrogen Balance in Rice-Wheat Systems of the Indo-Gangetic Plains
}

\author{
H. Pathak, C. Li, R. Wassmann, and J. K. Ladha*
}

\begin{abstract}
Crop growth simulation models provide a means to quantify the effects of climate, soil, and management on crop growth and biogeochemical processes in soil. The Denitrification and Decomposition (DNDC) model was evaluated for its ability to simulate $\mathbf{N}$ dynamics and balance in the rice (Oryza sativa $\mathbf{L}$.)-wheat (Triticum aestivum L.) cropping systems in the Indo-Gangetic Plains with various $\mathbf{N}$ and water management practices. The observed crop yield, $N$ uptake, and losses of $\mathbf{N}$ were in good agreement with the values predicted by the model. In the rice-wheat systems, current annual inputs of $N$ through fertilizer, manure, biological fixation, atmospheric deposition, and

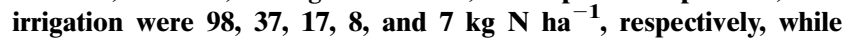
outputs through uptake, volatilization, leaching, and denitrification were 175, 14, 12, and $4 \mathrm{~kg} \mathrm{~N} \mathrm{ha}^{-1}$, respectively. The northwestern transects of the Indo-Gangetic Plains (Punjab and Haryana) showed greater yields and $N$ uptake because of a higher amount of $N$ use and more favorable climatic conditions than those in the eastern transects (Uttar Pradesh, Bihar, and West Bengal). Volatilization was the dominant $\mathrm{N}$ loss mechanism in Punjab and West Bengal while $\mathrm{NO}_{3}$ leaching was dominant in Bihar, Uttar Pradesh, and West Bengal. The simulated balance of $\mathrm{N}$ was negative in all the states. The largest depletion of soil $\mathbf{N}$ was estimated in Bihar, followed by Uttar Pradesh, Haryana, Punjab, and West Bengal. The study suggests that better $\mathbf{N}$ management is required to arrest the depletion of soil $\mathbf{N}$.
\end{abstract}

$\mathbf{R}$ ICE AND WHEAT are the two most important cereals for world food security. The rice-wheat production system occupies 21 million ha of cultivated land in the Asian subtropics (Dawe et al., 2003). In South Asia, the system occupies about 13 million ha, extending across the Indo-Gangetic floodplain (IGP) into the Himalayan foothills. The rice-wheat production system provides staple grain for more than 400 million people. During the Green Revolution era in the 1960s, production increases resulted from increases in both rice-wheat area and system productivity. But little additional land is available now and traditional farmlands are increasingly lost to urbanization. In addition, since most of the land is already double- and even triple-cropped, increasing cropping intensity is not a possible option for increasing production. Therefore, future demand for food will have to be met mainly through increases in production per unit of harvested area (Ladha et al., 2003).

In the rice-wheat systems, rice is grown in the summer months (June-October) under monsoon climatic condi-

H. Pathak, Unit of Simulation and Informatics, Indian Agricultural Research Inst., New Delhi, India; C. Li, Inst. for the Study of Earth, Oceans, and Space, Univ. of New Hampshire, Durham, NH; R. Wassmann, Inst. for Meteorology and Climate Research, GarmischPartenkirchen, Germany; and JK. Ladha, International Rice Research Inst., India Office, New Delhi 110 012, India. Received 26 May 2005.*Corresponding author (j.k.ladha@cgiar.org).

Published in Soil Sci. Soc. Am. J. 70:1612-1622 (2006).

Nutrient Management \& Soil \& Plant Analysis

doi:10.2136/sssaj2005.0165

(c) Soil Science Society of America

677 S. Segoe Rd., Madison, WI 53711 USA tions and wheat is grown during the cooler and drier winter months (November-March) after rice harvest. Generally, two to three rice seedlings (4-5 wk old) are transplanted in the puddled lowland field at 20- by $15-\mathrm{cm}$ spacing. Normally the fields are flooded $(2-4 \mathrm{~cm})$ until 2 wk before the rice harvest. Fertilizer dose varies in different regions of the IGP. Nitrogen is applied as urea in three splits, $50 \%$ at transplanting of rice and the remaining two splits top-dressed at tillering and panicle initiation stages. Phosphorus and $\mathrm{K}$ are applied as basal fertilizer on the day of planting. Manure is incorporated into soil $15 \mathrm{~d}$ before transplanting. Wheat $(100-120 \mathrm{~kg}$ seed ha ${ }^{-1}$ ) is sown in rows and three to four irrigations are given at the sowing, crown root initiation, maximum tillering, and flowering stages. All $\mathrm{P}$ and $\mathrm{K}$ and a half dose of $\mathrm{N}$ are applied at the sowing of wheat. The remaining $\mathrm{N}$ is topdressed in one or two splits at crown root initiation and maximum tillering stages with irrigation. Crops are harvested by combine in the upper IGP (Punjab, Haryana, and western Uttar Pradesh) and the straw is burnt before sowing wheat. In the lower IGP (eastern Uttar Pradesh, Bihar, and West Bengal), crops are harvested manually close to the ground using sickles and straw is removed from the field.

Nitrogen is the most widely used fertilizer nutrient and its consumption has increased substantially in recent decades. Before World War II, global N fertilizer application to agricultural soils was only $3 \mathrm{Mt}$, which rose to $84 \mathrm{Mt}$ in 2002. Nitrogen fertilizer consumption in India has also grown dramatically (Fig. 1). In 1950-1951, consumption of $\mathrm{N}$ fertilizer in the country was only $0.06 \mathrm{Mt}$, which increased to $11.31 \mathrm{Mt}$ in 2001-2002, an increase of about 190-fold in the last $50 \mathrm{yr}$ (Fertilizer Association of India, 2003). It rose steeply after the Green Revolution in the 1960s, mainly because of the availability of $\mathrm{N}$ fertilizer at low cost and the rapid adoption of modern, high-yielding N-responsive rice and wheat cultivars. The amount of compost consumed in Indian agriculture increased from $231.79 \mathrm{Tg}$ in 1980-1981 to 286.30 in 1993 1994 but decreased thereafter (Fertilizer Association of India, 2003). In 1999-2000, the consumption of compost was reduced to $137.58 \mathrm{Tg}$. Similarly, the area under green manure crop was about 5 to 6 million ha during 1980-1981 to 1993-1994 but has been reduced to only 2.25 million ha since 1996-1997. Therefore, fertilizer consumption in India needs to increase further in the coming years, as the country has to produce more food to feed its increasing population and the contribution of $\mathrm{N}$ through manure is not likely to increase.

Nitrogen can escape from soil-plant systems to water bodies and the atmosphere, creating pollution problems.

Abbreviations: DNDC, denitrification and decomposition model; FYM, farmyard manure; GIS, geographic information systems; IGP, Indo-Gangetic Plains; SOC, soil organic carbon. 


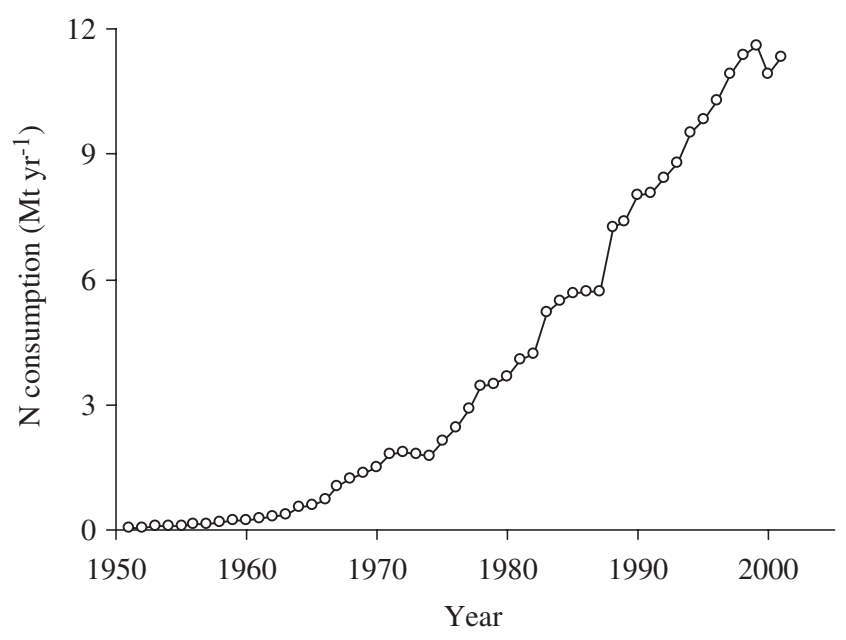

Fig. 1. Annual fertilizer $\mathbf{N}$ consumption in India since 1950.

The main loss pathways are (i) leaching, predominantly $\mathrm{NO}_{3}{ }^{-}$; (ii) denitrification, resulting in emissions of $\mathrm{N}_{2} \mathrm{O}$, $\mathrm{NO}$, and $\mathrm{N}_{2}$ gases; and (iii) $\mathrm{NH}_{3}$ volatilization. Efficient use of $\mathrm{N}$ fertilizer is one of the keys for obtaining a higher economic crop yield, increasing the use efficiency, and reducing various losses. It is of great importance, therefore, to optimize $\mathrm{N}$ management in crops because of not only the continuous increase in fertilizer prices but also environmental pollution (Ladha et al., 2005). The prerequisite of such a management system is to quantify the dynamics and losses of $\mathrm{N}$ at field, farm, and regional scales.

The 20th century witnessed an emergence of new technologies. Computer-based simulation modeling, decision support systems, GIS (geographic information systems), and management information systems predominate for solving the problems that agriculture faces today. During the last four decades, several simulation models have been developed and are now in use. Simulation models have previously been applied to provide recommendations for adequate nutrient supply for both optimal crop growth and minimal losses in Indian rice production, such as Thiyagarajan et al. (1997) using ORYZA, Aggarwal et al. (2006) using InfoCrop, and Pathak et al. (2004) using the Crop Estimation through Resource and Environment Synthesis (CERES)-Rice models. Simulation of the $\mathrm{N}$ budget, however, including the processes of mineralization, immobilization, nitrification, $\mathrm{NH}_{3}$ volatilization, and denitrification, requires more comprehensive soil-plant models that only recently became available. The ability of the models to include $\mathrm{C}$ and $\mathrm{N}$ cycling, such as CENTURY (Parton, 1996), CERES (Ritchie et al., 1998), DNDC (Li, 2000), and InfoCrop (Aggarwal et al., 2006), has generated intense interest in using them to project future outcomes of management scenarios for key environmental areas such as $\mathrm{N}$ losses. But these models are not yet at a stage where their predictive ability is satisfactory. Moreover, the models have hardly been used in tropical regions. The objectives of our study were to: (i) evaluate the DNDC model for its ability to simulate yield and $\mathrm{N}$ balances with various $\mathrm{N}$ and water management practices in the rice-wheat cropping system, and (ii) upscale the $\mathrm{N}$ balances to the rice-wheat cropping systems of the IGP.

\section{MATERIALS AND METHODS \\ Description of the Denitrification- Decomposition Model}

The DNDC model (Li, 2000) is a generic model of $\mathrm{C}$ and $\mathrm{N}$ biogeochemistry in agricultural ecosystems. In the model, SOC (soil organic C) resides in four major pools: plant residue (i.e., litter), microbial biomass, humads (or active humus), and passive humus. Each pool consists of two or three subpools with different specific decomposition rates. The model simulates $\mathrm{C}$ and $\mathrm{N}$ cycling in agroecosystems at a daily or subdaily time step. It consists of six interacting submodels: soil climate, plant growth, decomposition, nitrification, denitrification, and fermentation (Li et al., 1997). The soil climate submodel simulates soil temperature and moisture profiles based on soil physical properties, weather, and plant water use. The plant growth submodel calculates water and $\mathrm{N}$ uptake by vegetation, root respiration and plant growth, and partitioning of biomass into grain, stalk, and roots. Biomass partitioning is determined by the physiological parameters stored in the crop library files. For the empirical module, the fractions of grain, leaf plus stem, and root remain constant although the total biomass can vary.

The decomposition submodel simulates decomposition and $\mathrm{CO}_{2}$ production by soil microbes and $\mathrm{NH}_{3}$ volatilization. The nitrification submodel tracks growth of nitrifiers and turnover of $\mathrm{NH}_{4}{ }^{+}$to $\mathrm{NO}_{3}{ }^{-}$. The denitrification submodel simulates denitrification and the production of $\mathrm{NO}, \mathrm{N}_{2} \mathrm{O}$, and $\mathrm{N}_{2}$, whereas the fermentation submodel quantifies $\mathrm{CH}_{4}$ production, oxidation, and transport.

\section{Modeling Soil Nitrogen Dynamics}

The DNDC model simulates soil $\mathrm{N}$ dynamics by tracking several biogeochemical processes: decomposition, ammonification, $\mathrm{NH}_{4}^{+}-\mathrm{NH}_{3}$ equilibrium, microbial assimilation, plant uptake (grain plus straw), $\mathrm{NH}_{3}$ volatilization, nitrification, and denitrification (Li et al., 1992; Li, 2000). Nitrogen through inorganic fertilizer and manure is added as an input to the model. The contribution of $\mathrm{N}$ due to atmospheric deposition is calculated from the data on daily rainfall and its $\mathrm{N}$ content. Similarly, the $\mathrm{N}$ contribution of irrigation water is calculated from the data on irrigation provided as inputs to the model. Addition of $\mathrm{N}$ through biological fixation is empirically calculated using a crop-dependent coefficient. In the DNDC, when fresh organic matter is incorporated in the soils, it is partitioned into different pools of soil organic matter, which are of different quality (i.e., $\mathrm{C} / \mathrm{N}$ ratio) and hence different specific decomposition rates. Litter will be first assimilated into soil microbial biomass, which requires free $\mathrm{NH}_{4}{ }^{+}$or $\mathrm{NO}_{3}{ }^{-}$ions from the soil because of the difference in the $\mathrm{C} / \mathrm{N}$ ratio between the microbes and litter. Once the microbes die, their biomass will turn into humus. Active humus can be further transformed into passive humus through microbial activity. During the decomposition processes, a fraction of organic $\mathrm{N}$ is redistributed into the soil organic matter pools, and another part is turned into $\mathrm{NH}_{4}{ }^{+}$through ammonification. The free $\mathrm{NH}_{4}{ }^{+}$ions dissolved in the soil liquid phase can be absorbed by the plant roots, adsorbed by clay, or oxidized to $\mathrm{NO}_{3}{ }^{-}$by the nitrifiers. Driven by crop demand for $\mathrm{N} \mathrm{NH}_{4}{ }^{+}$is absorbed by the crop with the same opportunity as $\mathrm{NO}_{3}{ }^{-}$. The adsorption and desorption of $\mathrm{NH}_{4}{ }^{+}$are controlled by soil cation exchange capacity and $\mathrm{NH}_{4}{ }^{+}$concentration. The DNDC uses the Langmiur equation to quantify $\mathrm{NH}_{4}{ }^{+}$adsorption-desorption. 
Oxidation of $\mathrm{NH}_{4}{ }^{+}$is calculated with a nitrification routine in DNDC. When the concentration of free $\mathrm{NH}_{4}{ }^{+}$decreases in the soil liquid phase, the $\mathrm{NH}_{4}{ }^{+}$ions adsorbed on the clay surfaces are gradually released into the soil water, driven by the isotherm equilibrium.

The model simulates nitrification by tracking nitrifier activity and the $\mathrm{NH}_{4}{ }^{+}$concentration in the soil as influenced by environmental factors (soil temperature, moisture, and $\mathrm{pH}$; Martin et al., 1998). Growth and death rates of $\mathrm{NH}_{4}{ }^{+}$oxidizers are calculated based on DOC (dissolved organic C) concentration, temperature, and moisture.

Denitrification, that is, a sequential reduction of $\mathrm{NO}_{3}{ }^{-}$to $\mathrm{N}_{2}$ driven by denitrifying bacteria under anaerobic conditions, is controlled by soil moisture and redox potential (Stevens et al., 1998), temperature (Stanford et al., 1975), $\mathrm{pH}$ (Ashby et al., 1998), and substrate (e.g., DOC, $\mathrm{NO}_{3}, \mathrm{NO}_{2}, \mathrm{NO}$, and $\mathrm{N}_{2} \mathrm{O}$ ) concentrations. The DNDC model simulates relative growth rates of $\mathrm{NO}_{3}, \mathrm{NO}_{2}, \mathrm{NO}$, and $\mathrm{N}_{2} \mathrm{O}$ denitrifiers based on soil redox potential, concentrations of DOC, and $\mathrm{N}$ oxides. An "anaerobic balloon" scheme is used in the model to divide the soil matrix into aerobic and anaerobic parts. Tracking $\mathrm{O}_{2}$ diffusion and consumption in the soil profile, DNDC simulates swelling and shrinking of the "anaerobic balloon." Only the substrates allocated in the anaerobic part are involved in denitrification. Since denitrification is a typical sequential reaction, the basic laws of sequential chemical kinetic reactions are followed to calculate $\mathrm{NO}, \mathrm{N}_{2} \mathrm{O}$, and $\mathrm{N}_{2}$ fluxes. As an intermediate of the reactions, $\mathrm{NO}$ or $\mathrm{N}_{2} \mathrm{O}$ flux is determined by the rates of their production, consumption, and escape from the system. Diffusion rates of $\mathrm{NO}$ and $\mathrm{N}_{2} \mathrm{O}$ are calculated as a function of soil porosity, moisture, temperature, and clay content (Li, 2000).

The model calculates $\mathrm{NH}_{3}$ concentration in the soil liquid phase based on $\mathrm{NH}_{4}^{+}$and $\mathrm{OH}^{-}$concentrations. The concentration of $\mathrm{NH}_{4}{ }^{+}$in the soil profile is simulated by the decomposition submodel, which calculates turnover rates of soil organic matter (Li et al., 1992). The concentration of $\mathrm{OH}^{-}$is determined by soil $\mathrm{pH}$ and temperature based on Stumm and Morgan (1981, p. 418-503). The concentration of $\mathrm{NH}_{3}$ in the soil gas phase is proportional to the $\mathrm{NH}_{3}$ concentration in the liquid phase as well as soil temperature (Sutton et al., 1993). It is assumed that the daily emitted fraction of the gas-phase $\mathrm{NH}_{3}$ is related to the soil air-filled porosity and clay content because of their effects on $\mathrm{NH}_{3}$ gas diffusion ( $\left.\mathrm{Li}, 2000\right)$.

To predict soil $\mathrm{N}$ leaching, a process-based model must be capable of simulating both water movement and $\mathrm{N}$ transformation in soils. The model calculates soil moisture and water flow by tracking precipitation, plant interception, ponding water, bypass flow, infiltration, transpiration, and evaporation (Li et al., 1992). The decomposition, nitrification, and denitrification submodels contain a relatively complete suite of $\mathrm{N}$ transformation reactions, including mineralization, ammonification, nitrification, $\mathrm{NH}_{4}^{+}-\mathrm{NH}_{3}$ equilibrium, $\mathrm{NH}_{3}$ volatilization, and denitrification.

\section{Modeling Soil Water Movement}

In the DNDC, water movement is simulated using the processes of surface runoff, infiltration, gravitational and matric redistribution, evaporation, and transpiration based on Ritchie et al. (1988). Water available for infiltration includes rainfall, irrigation, snow melt, and surface storage. Water will infiltrate into the soil profile layer by layer until all the water on the surface is depleted or the infiltration is limited by a frozen layer or a water-restricting layer in the soil profile. In the latter two cases, water will remain in surface storage and a fixed fraction (0.5 as the default value based on Ritchie et al. [1988]) of the water above field capacity will drain every day. Transpiration and evaporation are simulated in the DNDC as the two major pathways for water loss from soil into the atmosphere. Potential evapotranspiration is estimated based on the Priestly and Taylor (1972) approach using solar radiation and temperature (Ritchie et al., 1988). Potential evapotranspiration is separated into potential evaporation and potential transpiration based on leaf area index. Potential transpiration is determined by crop water demand, which is calculated based on a daily increment of crop biomass and water requirement index (grams of water per gram dry matter). Potential evaporation is the difference between potential evapotranspiration and potential transpiration.

During a flooding period, the entire soil profile is saturated and water drainage is estimated based on the saturated hydraulic conductivity of soil. Supported with other hydraulic features existing in the DNDC, water content in each layer is calculated at an hourly time step. The gradient between water content and field capacity in each layer drives the water flow from layer to layer. Water flow from the bottom of the soil profile at the $0.5-\mathrm{m}$ depth is regarded as drainage flow.

\section{Model Evaluation}

Data generated in field experiments on the rice-wheat cropping system conducted in New Delhi (Pathak et al., 2002) and Modipuram (Shukla et al., 2004) in northwest India were used to evaluate the model. Apart from these experiments, data from some other experiments (Sachdev et al., 2000; Banerjee et al., 2002) conducted in New Delhi were also used.

New Delhi is situated at $28^{\circ} 40^{\prime} \mathrm{N}$ and $77^{\circ} 12^{\prime} \mathrm{E}$, at an altitude of $228 \mathrm{~m}$. The climate is subtropical semiarid, with average annual rainfall of $750 \mathrm{~mm}$, about $80 \%$ of which occurs from June to September. The mean maximum and minimum temperatures from July to October (rice or kharif season) are 35 and $18^{\circ} \mathrm{C}$, and from November to April (wheat or rabi season) are 22.6 and $6.7^{\circ} \mathrm{C}$, respectively. The alluvial soil of the experimental site was a Typic Ustochrept, loam in texture ( $210 \mathrm{~g}$ clay $\mathrm{kg}^{-1}, 330 \mathrm{~g}$ silt $\mathrm{kg}^{-1}$, and $460 \mathrm{~g}$ sand $\mathrm{kg}^{-1}$ ), with a bulk density of $1.38 \mathrm{~g} \mathrm{~cm}^{-3}, \mathrm{pH}$ (1:2 soil/water) of 8.1 , electrical conductivity of $0.48 \mathrm{dS} \mathrm{m}^{-1}$, cation exchange capacity of $7.3 \mathrm{cmol} \mathrm{kg}^{-1}$, and organic $\mathrm{C}$, total $\mathrm{N}$, Olsen $\mathrm{P}$, and $\mathrm{NH}_{4} \mathrm{OAc}$-extractable $\mathrm{K}$ contents of $4.5,0.30,0.007$, and $0.13 \mathrm{~g} \mathrm{~kg}^{-1}$, respectively (Pathak et al., 2002).

Modipuram is located at $29^{\circ} 4^{\prime} \mathrm{N}, 77^{\circ} 46^{\prime} \mathrm{E}$, at an altitude of $237 \mathrm{~m}$, in Uttar Pradesh (Shukla et al., 2004). The climate of the region is semiarid subtropical, with dry, hot summers and cold winters. The average annual rainfall is $810 \mathrm{~mm}, 75 \%$ of which is received during July to September. Mean maximum and minimum temperatures are 34.0 and $24.1^{\circ} \mathrm{C}$ during the rice season (July-October) and 26.9 and $10.1^{\circ} \mathrm{C}$ during the wheat (November-April) season. The soil of the experimental sites was a Typic Ustochrept (Sobhapur sandy loam), alkaline in reaction ( $\mathrm{pH} 8.2)$, sandy loam in texture (160 $\mathrm{g}$ clay $\mathrm{kg}^{-1}$,

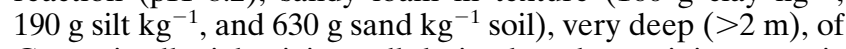
Gangetic alluvial origin, well drained, and containing organic $\mathrm{C}$, total $\mathrm{N}$, Olsen $\mathrm{P}$, and $\mathrm{NH}_{4} \mathrm{OAc}$-extractable $\mathrm{K}$ contents of $8.3,0.80,0.025$, and $0.31 \mathrm{~g} \mathrm{~kg}^{-1}$, respectively.

The genetic coefficients for the rice and wheat cultivars, used as model inputs to describe crop phenology in response to temperature and photoperiod, were estimated by adjusting the coefficients until close matches were achieved between simulated and observed phenology and yield. The total thermal time requirements (above a base temperature of $10^{\circ} \mathrm{C}$ ) for rice and wheat cultivars were calculated to be 2250 and 1200 degree days, respectively. Rate constants of rice crop development in the vegetative and reproductive stages were 0.015 and 
$0.044 \mathrm{~d}^{-1}$, respectively, while for the wheat crop the values were 0.04 and $0.026 \mathrm{~d}^{-1}$, respectively.

\section{Sensitivity Analyses}

Sensitivity of the model to changes in the amount and source of $\mathrm{N}$ fertilizer and irrigation for yield and $\mathrm{N}$ dynamics was analyzed using the baseline data (weather, soil, cultivar, location, and other inputs) of the crop year 1999-2000 in New Delhi. The rice crop was transplanted on 15 July and harvested on 25 Oct. 1999, while wheat crop was sown on 25 Nov. 1999 and harvested on 25 Mar. 2000. The simulation was started on 1 Jan. 1999 and ended on 31 Dec. 2000.

\section{Upscaling Nitrogen Balances from Rice-Wheat Systems in the Indo-Gangetic Plains}

The approach for upscaling $\mathrm{N}$ balances using the DNDC model and GIS is depicted in Fig. 2. The required input parameters of the DNDC model-consisting of daily meteorological data (maximum and minimum air temperatures, precipitation, and solar radiation), soil properties (SOC, clay contents, $\mathrm{pH}$, and bulk density), field area under different ricewheat systems, and fertilizer and manure use-were compiled in a GIS database. The IGP is spread out across several states and the states are further divided into administrative boundaries called districts. Since many of the statistical data were district based, the district was chosen as the basic geographic unit of the database to maintain the maximum accuracy of the original datasets. The meteorological data were obtained from the National Climatic Data Center in the USA, and consisted of daily records of more than 20 climatic stations across the IGP. Soil properties were compiled from the National Bureau of Soil Survey and Land Use Planning (1998) and Velayutham and Bhattacharya (2000). Field area per district under ricewheat cropping systems was compiled from published data
(Yadav and Subba Rao, 2001, p. 96). Data on N and manure use in rice and wheat in different states were collected from the Fertilizer Association of India (2003) and Ministry of Agriculture and Cooperation (2000). As data on irrigation water use in rice-wheat systems were not available, simulation was done for continuous flooding for rice and five irrigations for wheat based on the common on-farm practices of the region. Nitrogen was applied as urea, broadcast in three splits $(1 / 2$ at $1 \mathrm{~d}$ after transplanting [DAT], $1 / 4$ at 30 DAT, and $1 / 4$ at 55 DAT in rice and $1 / 2$ at $1 \mathrm{~d}$ after sowing [DAS], $1 / 4$ at $20 \mathrm{DAS}$, and $1 / 4$ at 45 DAS in wheat). For both systems, the field was plowed three times with a moldboard plow before rice transplanting and wheat sowing. Rice was transplanted on 15 July and wheat was sown on 25 November. The model calculated annual yield, uptake in grain plus straw, and losses of $\mathrm{N}$ through $\mathrm{NH}_{3}$ volatilization, leaching, and denitrification for two scenarios: (i) low SOC and (ii) high SOC. The scenario for minimum losses includes the minimum values of $\mathrm{SOC}, \mathrm{pH}$, and bulk density and the maximum value of clay content of the soil, whereas the scenario for maximum emission includes the maximum values of SOC, $\mathrm{pH}$, and bulk density and the minimum value of clay content of the soil. The average values of the $\mathrm{N}$ budget of these two scenarios are reported here. In the IGP, the farmers remove both grain and straw of rice and wheat at harvest; however, in the upper IGP (Punjab, Haryana and western Uttar Pradesh) rice straw is burnt in the field before sowing wheat. Burning of straw results in the loss of almost the entire amount of $\mathrm{N}$ to the atmosphere (Dobermann and Fairhurst, 2000). Thus addition of $\mathrm{N}$ through crop residues has not been taken into consideration in this study.

\section{RESULTS AND DISCUSSION Performance of the Model}

Predicted grain yields agreed well with observed yields in New Delhi and Modipuram for rice and wheat

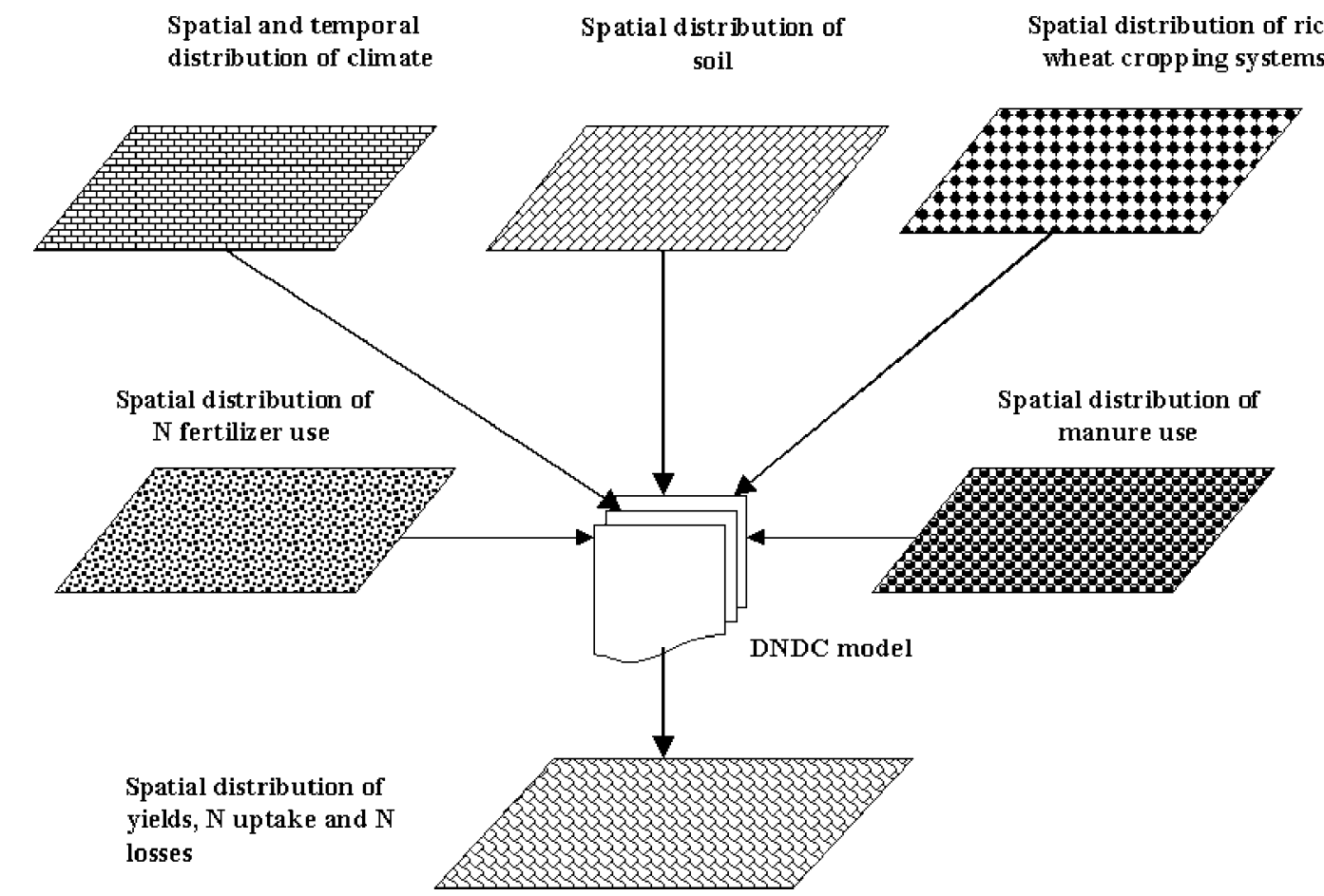

Fig. 2. Approaches for the upscaling of $\mathbf{N}$ dynamics in rice-wheat cropping systems in the Indo-Gangetic Plain using the DenitrificationDecomposition (DNDC) model. 
Table 1. Simulated and observed yield, $\mathbf{N}$ uptake, and losses of $\mathrm{N}$ with application of $120 \mathrm{~kg} \mathrm{~N} \mathrm{ha}^{-1}$ in rice and wheat in the Indo-Gangetic Plain.

\begin{tabular}{|c|c|c|c|c|}
\hline \multirow[b]{2}{*}{ Parameter } & \multicolumn{2}{|c|}{ Rice } & \multicolumn{2}{|c|}{ Wheat } \\
\hline & Observed $\dagger$ & Simulated & Observed $\dagger$ & Simulated \\
\hline Grain yield, $\mathrm{kg} \mathrm{ha}^{-1}$ & $\begin{array}{l}6500-6800 \\
114-126\end{array}$ & $\begin{array}{l}6513-7088 \\
115-133\end{array}$ & $\begin{array}{l}4100-6100 \\
84-139\end{array}$ & $\begin{array}{l}4283-617 \\
91-131\end{array}$ \\
\hline $\begin{array}{l}\mathrm{NH}_{3} \text { volatilization, } \\
\mathbf{k g ~ N ~ h a}^{-1}\end{array}$ & 20-30 & $25-30$ & $20-40$ & 40-44 \\
\hline $\begin{array}{l}\mathrm{NO}_{3} \text { leaching, } \\
\mathrm{kg} \mathrm{N} \mathrm{ha}^{-1}\end{array}$ & $10-15$ & 12-15 & $10-15$ & 14-19 \\
\hline $\begin{array}{l}\text { Denitrification, } \\
\text { kg N ha }^{-1}\end{array}$ & $10-15$ & 10-11 & 5-10 & 9-11 \\
\hline
\end{tabular}

$\dagger$ From Pathak et al. (2002, 2003b), Shukla et al. (2004), Banerjee et al. (2002), Aulakh et al. (2001), and Bijay-Singh et al. (2002).

(Table 1). The model also simulated uptake of $\mathrm{N}$ by rice and wheat satisfactorily. The model predicted total annual losses of $\mathrm{N}$ from leaching, $\mathrm{NH}_{3}$ volatilization, and denitrification from rice-wheat fields in northwest India similar to those observed in the experiments conducted at the New Delhi site (Banerjee et al., 2002) and various other places in the region (Aulakh et al., 2001; Aulakh and Bijay-Singh, 1997; Katyal et al., 1985, 1987; BijaySingh et al., 2002). Some earlier studies have shown that the leaching loss of $\mathrm{N}$ from soils in the IGP is 10 to $15 \mathrm{~kg} \mathrm{~N} h a^{-1}$ while the $\mathrm{NH}_{3}$ volatilization loss is 20 to $30 \mathrm{~kg} \mathrm{~N} \mathrm{ha}^{-1}$ with application of $120 \mathrm{~kg} \mathrm{~N} \mathrm{ha}^{-1}$ in rice and wheat (Katyal et al., 1987; Aulakh and Bijay-Singh, 1997; Parashar et al., 1998). On an average, denitrification losses of $\sim 10$ to 15 and 5 to $10 \mathrm{~kg} \mathrm{~N} \mathrm{ha}^{-1}$ in rice and wheat, respectively, with application of $120 \mathrm{~kg} \mathrm{~N}$ ha ${ }^{-1}$ have been reported (Srivastava and Singh, 1996). The model also simulated similar magnitude of losses of $\mathrm{N}$ (Table 1). The DNDC model has been widely used during the last $12 \mathrm{yr}$ by many researchers in various parts of the world (Brown et al., 2002; Butterbach-Bahl et al., 2004; Cai et al., 2003; Li et al., 1992, 1997, 2001, 2004; Pathak et al., 2005; Smith et al., 2002, 2004; Saggar et al., 2004). Results showed that the DNDC was able to simulate the $\mathrm{N}$ fluxes from soil quite satisfactorily. The limitation of this study, however, was the availability of only a few measured data on $\mathrm{NH}_{3}$ loss, $\mathrm{NO}_{3}$ leached, and denitrification, because of which detailed comparison of the observed and simulated values has not been possible. Moreover, there is no single experiment in south Asia where all the loss measurements have been done simultaneously. Therefore, research should be performed to quantify all the components of the $\mathrm{N}$ budget in some selected locations in different agroecological zones.

\section{Sensitivity Analyses}

Sensitivity of the model was analyzed for the effect of various $\mathrm{N}$ and water management practices on yield, $\mathrm{N}$ uptake, and $\mathrm{N}$ losses in rice and wheat in Delhi. Yield as well as $\mathrm{N}$ uptake of rice increased with $\mathrm{N}$ application up to $300 \mathrm{~kg} \mathrm{ha}^{-1}$, but with small increases at rates above $180 \mathrm{~kg} \mathrm{ha}^{-1}$ (Table 2). Volatilization of $\mathrm{NH}_{3}$, the major loss mechanism of $\mathrm{N}$, increased as the $\mathrm{N}$ application rate increased. High soil pH (8.2) along with high temperature was responsible for such a high loss of $\mathrm{N}$ through volatilization. Leaching and denitrification losses of $\mathrm{N}$ remained similar at all levels of $\mathrm{N}$ application. In this simulation, the soil remained flooded and anaerobic conditions prevailed throughout the rice-cropping period; as a result, there was no nitrification, which requires aerobic conditions to form $\mathrm{NO}_{3}$. As no $\mathrm{NO}_{3}$ was formed, loss of $\mathrm{N}$ from leaching and denitrification was limited during rice cropping.

Urea at $60 \mathrm{~kg} \mathrm{~N} \mathrm{ha}^{-1}$ plus $60 \mathrm{~kg} \mathrm{~N}^{-1}$ from FYM (farmyard manure) reduced grain yield and $\mathrm{N}$ uptake compared with $120 \mathrm{~kg} \mathrm{~N}^{-1}$ through urea alone (Table 2). Slow mineralization of $\mathrm{N}$ from FYM resulted in lower $\mathrm{N}$ availability, which was responsible for the decrease in yield and $\mathrm{N}$ uptake (Pathak et al., 2002).

Water management also influenced simulated yield, $\mathrm{N}$ uptake, and losses of $\mathrm{N}$ from soil in rice (Table 2). Treatments with continuous flooding gave higher yields and $\mathrm{N}$ uptake than midseason drainage treatments. However, one and two midseason drainages of $10 \mathrm{~d}$ each increased denitrification and leaching and decreased volatilization compared with continuously flooded soil. As midseason drainage resulted in aerobic soil conditions with enhanced nitrification forming $\mathrm{NO}_{3}{ }^{-}$, denitrification and leaching were enhanced (Aulakh et al., 1992).

Yield and $\mathrm{N}$ uptake of wheat increased with $\mathrm{N}$ application up to $300 \mathrm{~kg} \mathrm{ha}^{-1}$, but with small increases at rates above $120 \mathrm{~kg} \mathrm{ha}^{-1}$ (Table 3). At lower $\mathrm{N}$ levels (up to $60 \mathrm{~kg} \mathrm{~N} \mathrm{ha}^{-1}$ ), there was a similar magnitude of $\mathrm{N}$ loss from volatilization, leaching, and denitrification. With $120 \mathrm{~kg} \mathrm{~N} \mathrm{ha}{ }^{-1}$ and more, however, volatilization increased with $\mathrm{N}$ application (Table 3). Unlike in rice, leaching and denitrification losses of $\mathrm{N}$ were substantial at all levels of $\mathrm{N}$ application in wheat.

Table 2. Sensitivity analysis for effects of different rates of $\mathbf{N}$ application as urea and manure, and different water regimes on simulated yield, $\mathbf{N}$ uptake, and $\mathbf{N}$ losses in rice in Delhi.

\begin{tabular}{|c|c|c|c|c|c|c|}
\hline Urea $\mathbf{N}$ & Water regime $\dagger$ & Grain yield & Uptake & Volatilization & Denitrification & Leaching \\
\hline $\mathrm{kgN} \mathrm{ha}^{-1}$ & & $\operatorname{kg~ha}^{-1}$ & 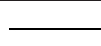 & 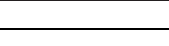 & & \\
\hline 0 & CF & 1690 & 33 & 7 & 9 & 5 \\
\hline 60 & CF & 4583 & 90 & 12 & 9 & 5 \\
\hline 120 & CF & 7020 & 138 & 26 & 9 & 5 \\
\hline 180 & $\mathbf{C F}$ & 8730 & 172 & 53 & 9 & 5 \\
\hline 240 & CF & 9793 & 193 & 91 & 9 & 6 \\
\hline 300 & CF & 10223 & 201 & 134 & 10 & 12 \\
\hline $60(+60) \div$ & CF & 6338 & 125 & 19 & 9 & 5 \\
\hline 120 & 1MD & 6888 & 136 & 22 & 10 & 10 \\
\hline 120 & $2 M D$ & 6760 & 133 & 21 & 10 & 11 \\
\hline
\end{tabular}

$\dagger \mathrm{CF}=$ continuous flooding; $1 \mathrm{MD}$ and $2 \mathrm{MD}=$ one and two midseason drainages, respectively.

$\ddagger$ Plus $60 \mathrm{~kg} \mathrm{~N} \mathrm{ha}^{-1}$ from farmyard manure. 
Table 3. Sensitivity analysis for effects of different rates of $\mathbf{N}$ application as urea and manure on simulated yield, $N$ uptake, and $\mathrm{N}$ losses in wheat in Delhi.

\begin{tabular}{|c|c|c|c|c|c|}
\hline Urea $\mathbf{N}$ & $\begin{array}{l}\text { Grain } \\
\text { yield }\end{array}$ & Uptake & Volatilization & Denitrification & Leaching \\
\hline $\operatorname{kgNha}^{-1}$ & $\mathrm{~kg} \mathrm{ha}^{-1}$ & & kg & N ha ${ }^{-1}$ & \\
\hline $\mathbf{0}$ & 1728 & 37 & 3 & 4 & 6 \\
\hline 60 & 4358 & 92 & 6 & 5 & 7 \\
\hline 120 & 4938 & 105 & 32 & 10 & 18 \\
\hline 180 & 5278 & 112 & 62 & 14 & 35 \\
\hline 240 & 5575 & 118 & 93 & 16 & 53 \\
\hline 300 & 5823 & 123 & 126 & 18 & 70 \\
\hline $60(+60) \dagger$ & 4750 & 101 & 9 & 10 & 9 \\
\hline
\end{tabular}

$\dagger$ Plus $60 \mathrm{~kg} \mathrm{~N} \mathrm{ha}{ }^{-1}$ from farmyard manure.

Substituting $60 \mathrm{~kg} \mathrm{~N} \mathrm{ha}^{-1}$ from FYM for $60 \mathrm{~kg} \mathrm{~N} \mathrm{ha}^{-1}$ from urea reduced grain yield, $\mathrm{N}$ uptake, and losses of $\mathrm{N}$ by volatilization and leaching in wheat compared with the application of $120 \mathrm{~kg} \mathrm{~N} \mathrm{ha}^{-1}$ through urea alone (Table 3). Slow mineralization of $\mathrm{N}$ from FYM, resulting in lower $\mathrm{N}$ availability, was responsible for such a decrease in yield, $\mathrm{N}$ uptake, and $\mathrm{N}$ losses.

\section{Model Applications}

The model was applied to calculate $\mathrm{N}$ outputs through crop uptake, leaching, volatilization, and denitrification in a rice-wheat system in Delhi using the baseline data (weather, soil, cultivar, location, and other inputs) of the crop year 1999-2000 (Table 4). The treatments included $\mathrm{N}$ levels ranging from 120 to $360 \mathrm{~kg} \mathrm{~N} \mathrm{ha}^{-1}$ in the cropping system through urea, FYM, and their combinations. The rice crop was transplanted on 15 July and harvested on 25 Oct. 1999. The wheat crop was sown on 25 Nov. 1999 and harvested on 25 Mar. 2000. The simulation was started on 1 Jan. 1999 and ended on 31 Dec. 2000.

Uptake of $\mathrm{N}$ varied between 87 and $259 \mathrm{~kg} \mathrm{~N} \mathrm{ha}^{-1}$, with the lowest in the FYM-alone treatment and the highest with the application of $360 \mathrm{~kg} \mathrm{~N} \mathrm{ha}^{-1}$ through urea. Loss of $\mathrm{N}$ from volatilization was substantial, ranging from $18 \mathrm{~kg} \mathrm{ha}^{-1}$ in the FYM treatment to $96 \mathrm{~kg} \mathrm{ha}^{-1}$ with $360 \mathrm{~kg} \mathrm{~N}$ through urea alone (Table 4). Loss from volatilization was greater in the treatments with $\mathrm{N}$ application through urea alone. In a subtropical, semiarid climate with high soil $\mathrm{pH}$, loss due to $\mathrm{NH}_{3}$ volatilization is very high when $\mathrm{N}$ is topdressed as urea (Banerjee et al., 2002). The substitution for urea by FYM reduced the loss, whereas a full dose of $\mathrm{N}$ through FYM had the lowest volatilization loss. This was due to the lower concentration of dissolved $\mathrm{NH}_{4}{ }^{+}$in soil solution because of the slower release of $\mathrm{N}$ from FYM than from urea, which is hydrolyzed at a much faster rate (Banerjee et al., 2002).

In ideal lowland rice fields with fine-textured soils, leaching losses of $\mathrm{N}$ are low because of restricted percolation (Buresh et al., 1989; George et al., 1992). In coarse-textured permeable soils, however, the loss of $\mathrm{N}$ through leaching can be substantial because of high percolation and drainage of water in these soils, along with which $\mathrm{NO}_{3}{ }^{-}$is leached downward (Katyal et al., 1985; Bijay-Singh et al., 2002; Shrestha and Ladha, 2002). High $\mathrm{NO}_{3}{ }^{-}$content in soil is expected in ricewheat cropping systems because of the drying of the soil at the end of the rice crop, which favors nitrifica-
Table 4. Impact of different rates and sources of $N$ on the various components of $\mathbf{N}$ balance in a rice-wheat system in Delhi.

\begin{tabular}{|c|c|c|c|c|c|}
\hline Parameter & $\begin{array}{c}\text { Urea } \\
\mathbf{( 1 2 0 )} \dagger\end{array}$ & $\begin{array}{l}\text { Urea } \\
(240)\end{array}$ & $\begin{array}{l}\text { Urea } \\
(\mathbf{3 6 0})\end{array}$ & $\begin{array}{c}\text { Urea }+ \\
\text { manure (240) }\end{array}$ & $\begin{array}{c}\text { Manure } \\
(\mathbf{2 4 0})\end{array}$ \\
\hline & & & $-\mathrm{kg}$ & $\mathrm{ha}^{-1}$ & \\
\hline \multicolumn{6}{|l|}{ Model inputs } \\
\hline Fertilizer & 120 & 240 & 360 & 120 & $\mathbf{0}$ \\
\hline Manure & $\mathbf{0}$ & $\mathbf{0}$ & $\mathbf{0}$ & 120 & 240 \\
\hline Fixation $\neq$ & 19 & 21 & 23 & 19 & 17 \\
\hline Total input & 139 & 261 & 383 & 259 & 257 \\
\hline \multicolumn{6}{|l|}{ Model outputs } \\
\hline Uptake & 144 & 210 & 259 & 168 & 87 \\
\hline $\mathrm{NH}_{3}$ volatilization & 19 & 52 & 96 & 23 & 18 \\
\hline $\mathrm{NO}_{3}$ leaching & 10 & 16 & 31 & 10 & 10 \\
\hline Denitrification & 15 & 20 & 23 & 14 & 14 \\
\hline Total output & 188 & 298 & 409 & 215 & 129 \\
\hline Balance & -49 & -37 & -26 & 44 & 128 \\
\hline
\end{tabular}

$\dagger$ Numbers in parentheses are the total $\mathbf{N}$ applied $\left(\mathrm{kg} \mathrm{N} \mathrm{ha}^{-1}\right)$ in the rice-wheat system. Total $\mathbf{N}$ was divided equally for rice and wheat and applied in three splits each. The period of simulation was from 1 Jan. to 31 Dec. 1999.

$\$$ Fixation includes inputs through atmospheric deposition, biological fixation, and irrigation.

tion. Accumulated $\mathrm{NO}_{3}-\mathrm{N}$ is prone to loss by leaching during soil flooding in rice (Buresh et al., 1989; George et al., 1992). Total leaching loss of $\mathrm{N}$ varied from 10 to $31 \mathrm{~kg} \mathrm{ha}^{-1}$ (Table 4). Losses were similar $\left(10 \mathrm{~kg} \mathrm{ha}^{-1}\right)$ when 120,240 , and $240 \mathrm{~kg} \mathrm{~N}^{-1}$ was applied through urea, urea plus FYM, or FYM alone, respectively, but the application of higher amounts of urea-N increased the leaching loss. The $\mathrm{N}$ loss due to denitrification ranged from $14 \mathrm{~kg} \mathrm{ha}^{-1}$ in the FYM treatment to $23 \mathrm{~kg} \mathrm{ha}^{-1}$ in the $360 \mathrm{~kg} \mathrm{~N}^{-1}$ urea treatment.

Treatments with urea-N alone had negative balances of $\mathrm{N}$ ranging from 26 to $49 \mathrm{~kg} \mathrm{~N}^{-1}$, whereas the application of FYM, either in combination with urea or alone, showed a positive $\mathrm{N}$ balance (Table 4). Depletion of soil $\mathrm{N}$ in the rice-wheat cropping system was also reported by Bhandari et al. (2002) and Regmi et al. (2002) when the recommended level of $\mathrm{N}$ $\left(120 \mathrm{~kg} \mathrm{~N} \mathrm{ha}^{-1}\right.$ in rice and wheat each) was applied through urea alone. In our study, a larger amount of urea application reduced the depletion of $\mathrm{N}$ from the soil, suggesting that the present level of $\mathrm{N}$ application is inadequate to arrest the depletion of soil $\mathrm{N}$ and that a larger amount of fertilizer $\mathrm{N}$ with better management to reduce $\mathrm{N}$ loss and improve $\mathrm{N}$ use efficiency is required to maintain the balance (Ladha et al., 2005). A positive $\mathrm{N}$ balance in the FYM treatment suggested the need to apply $\mathrm{N}$ through organic sources to sustain the $\mathrm{N}$ balance in soil under the rice-wheat cropping system.

\section{Upscaling Nitrogen Balances in Rice-Wheat Systems of the Indo-Gangetic Plains}

\section{Database of Rice-Wheat Cropping Systems and Soil}

The total area under the rice-wheat system in the five states-Punjab, Haryana, Uttar Pradesh, Bihar, and West Bengal-located in the IGP is 7.55 million ha (Yadav and Subba Rao, 2001, p. 96). The largest area is in Uttar Pradesh (3.46 million ha), followed by Punjab and Bihar (Table 5). There are some other rice-wheat growing areas in India ( $\sim 2.5$ million ha) located outside the IGP, but these were not considered in this study. 
Table 5. Total area, fertilizer and manure use, and average yields of the rice-wheat systems in different states in the Indo-Gangetic Plain.

\begin{tabular}{|c|c|c|c|c|c|}
\hline State & Area $\dagger$ & Fertilizer use $\ddagger$ & Manure useII & Rice yield $\$$ & Wheat yield: \\
\hline & thousand ha & $\mathrm{kg} \mathrm{N} \mathrm{ha}^{-1} \mathrm{yr}^{-1}$ & $\mathrm{kgCha}^{-1} \mathrm{yr}^{-1}$ & 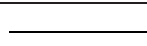 & \\
\hline Uttar Pradesh & 3464 & 91 & 200 & 3265 & 2764 \\
\hline Punjab & 1750 & 139 & 1000 & 5019 & 4696 \\
\hline Bihar & 1496 & 70 & 100 & 2310 & 2061 \\
\hline Haryana & 801 & 110 & 400 & 3580 & 4167 \\
\hline West Bengal & 233 & 80 & 2000 & 3388 & 2187 \\
\hline
\end{tabular}

$\dagger$ From Yadav and Subba Rao (2001, p. 96).

$\ddagger$ From Fertilizer Association of India (2003).

If From Ministry of Agriculture and Cooperation (2000).

Fertilizer use is the highest in Punjab $\left(139 \mathrm{~kg} \mathrm{~N}^{-1}\right.$ $\mathrm{yr}^{-1}$ ) and it decreases gradually in the eastern part of the IGP. In Bihar and West Bengal, fertilizer use is 70 and $80 \mathrm{~kg} \mathrm{~N} \mathrm{ha}^{-1} \mathrm{yr}^{-1}$, respectively. Manure use also follows a similar trend, except in West Bengal, where it is the highest. Yields of rice and wheat in these states give a mirror image of $\mathrm{N}$ use through manure and fertilizer. Yields gradually decrease from Punjab (5019 and $4696 \mathrm{~kg} \mathrm{ha}^{-1}$ for rice and wheat, respectively) to Bihar (2310 and $2061 \mathrm{~kg} \mathrm{ha}^{-1}$ for rice and wheat, respectively) but increase in West Bengal, where a higher amount of $\mathrm{N}$ is used in the rice-wheat system. Favorable climatic conditions in the northwestern transects of the IGP (Punjab and Haryana) are also responsible for larger yield and $\mathrm{N}$ uptake than those in the eastern transects (Pathak et al., 2003a).

The spatial distribution of SOC, clay content, $\mathrm{pH}$, and bulk density of soils in the rice-wheat growing regions of the IGP is presented at the district scale in Fig. 3. Being in the tropical region, with a lighter soil texture and inadequate recycling of organic matter, the SOC content of the soil is low, with a majority of soils containing SOC $<0.5 \%$ (Fig. 3a). The soils are lighter in texture, with clay content varying from 20 to $30 \%$ (Fig. 3b). A majority of the soils are alkaline $(\mathrm{pH}>7)$, and some soils in the lower transect of the IGP (parts of Bihar and West Bengal) are acidic in reaction (Fig. 3c). The soils of the upper transect (Punjab and Haryana) have a higher bulk density than those from the lower transects (Fig. 3d).

\section{Balance of Nitrogen}

Current inputs in the rice-wheat system of the IGP ranged from 107 to $224 \mathrm{~kg} \mathrm{~N} \mathrm{ha}^{-1}$, with an average of $166 \mathrm{~kg} \mathrm{~N} \mathrm{ha}^{-1}$ (Table 6). Fertilizer was the major $\mathrm{N}$ input

\begin{tabular}{ccccc}
\hline Legend & (a) SOC, $\%$ & $\begin{array}{c}\text { (b) Clay, } \\
\%\end{array}$ & $\begin{array}{c}\text { (c) } \\
\mathrm{pH}\end{array}$ & $\begin{array}{c}\text { (d) Bulk density, } \\
\mathrm{Mg} \mathrm{m}^{-3}\end{array}$ \\
\hline$<0.3$ & $<20$ & $<6$ & $<1.35$ \\
$0.3-0.5$ & $20-30$ & $6-$ & $1.35-1.50$ \\
& $>0.5$ & $>30$ & $>7.5$ & $>1.50$
\end{tabular}
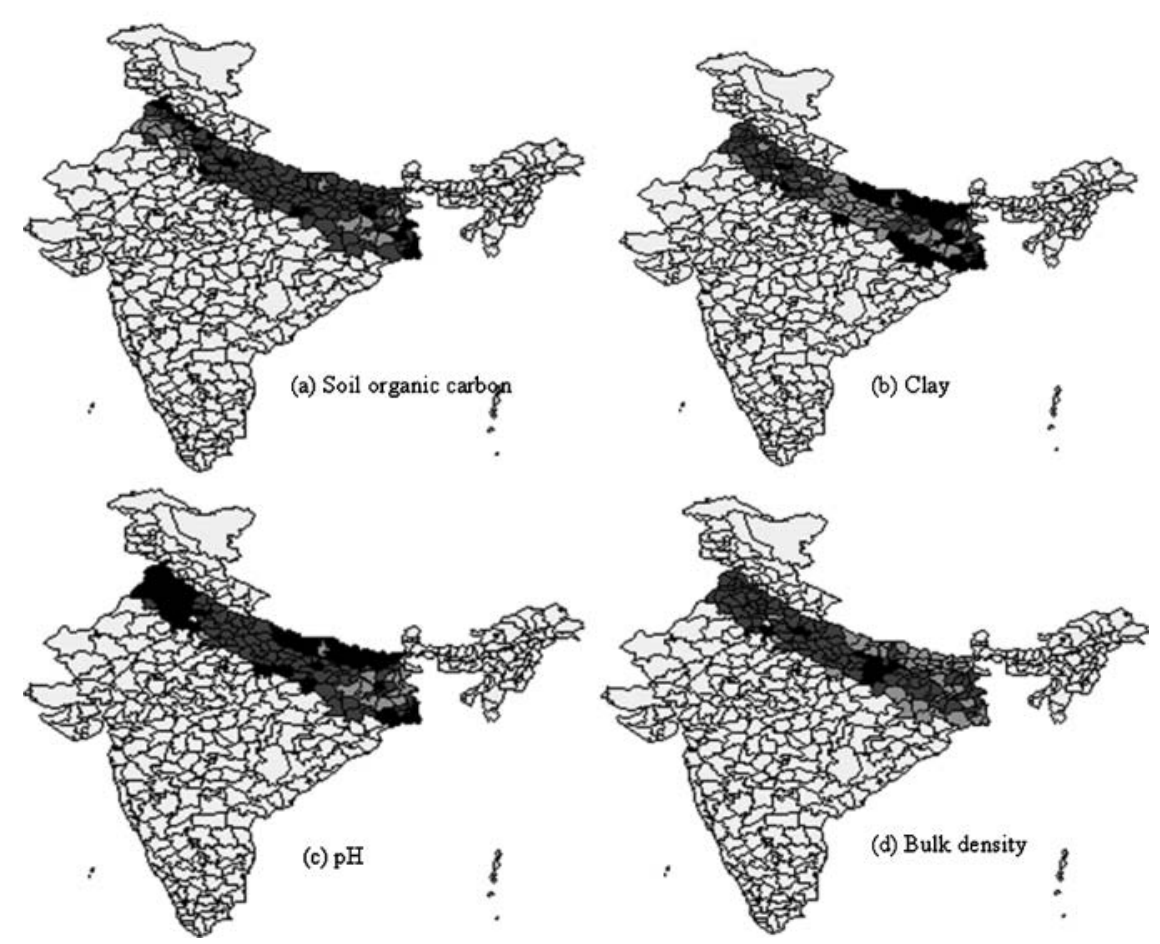

Fig. 3. Spatial distribution of (a) soil organic C (SOC), (b) clay content, (c) pH, and (d) bulk density of soils of the Indo-Gangetic Plain. 
Table 6. Simulated annual inputs, outputs, and balances of $N$ in the rice-wheat systems for different states of the Indo-Gangetic Plain using the current farmers' practices.

\begin{tabular}{|c|c|c|c|c|c|c|}
\hline Parameters & Punjab & Haryana & $\begin{array}{c}\text { Uttar } \\
\text { Pradesh }\end{array}$ & Bihar & $\begin{array}{c}\text { West } \\
\text { Bengal }\end{array}$ & Average \\
\hline & & & $\mathrm{kg} \mathrm{N} \mathrm{ha}^{-}$ & $1 \mathrm{yr}^{-1}$ & & \\
\hline \multicolumn{7}{|l|}{ Input } \\
\hline Fertilizer & 139 & 110 & 91 & 70 & 80 & 98 \\
\hline Manure & 50 & 20 & 10 & 5 & 100 & 37 \\
\hline $\begin{array}{c}\text { Atmospheric } \\
\text { deposition }\end{array}$ & 4 & 5 & 7 & 11 & 12 & 7 \\
\hline $\begin{array}{c}\text { Biological } \\
\text { fixation }\end{array}$ & 19 & 18 & 17 & 17 & 17 & 17 \\
\hline Irrigation & 12 & 10 & 6 & 4 & 2 & 7 \\
\hline Total input & 224 & 163 & 131 & 107 & 211 & 166 \\
\hline \multicolumn{7}{|l|}{ Output } \\
\hline Uptake & 217 & 192 & 168 & 157 & 168 & 175 \\
\hline $\begin{array}{l}\mathrm{NH}_{3} \\
\text { volatilization }\end{array}$ & 21 & 12 & 8 & 5 & 31 & 14 \\
\hline $\mathrm{NO}_{3}$ leaching & 4 & 2 & 9 & 11 & 22 & 12 \\
\hline ation & 4 & 2 & 4 & 5 & 9 & 4 \\
\hline Total output & 246 & 208 & 189 & 178 & 230 & 205 \\
\hline Balance & -22 & -45 & -58 & -71 & -19 & -39 \\
\hline
\end{tabular}

in most parts of the IGP. Average inputs of $\mathrm{N}$ through fertilizer, manure, atmospheric deposition, biological fixation, and irrigation were 98, 37, 7, 17, and $7 \mathrm{~kg} \mathrm{~N} \mathrm{ha}{ }^{-1}$, respectively. Total simulated output varied between 178 and $246 \mathrm{~kg} \mathrm{~N}^{-1}$ and plant uptake was the major $\mathrm{N}$ sink. The upper transect of the IGP showed a higher uptake because of higher $\mathrm{N}$ use and yield than the lower transect.

The simulated $\mathrm{N}$ losses from rice-wheat cropping systems through $\mathrm{NH}_{3}$ volatilization, leaching, and denitrification were 5 to 31,2 to 22 , and 2 to $9 \mathrm{~kg} \mathrm{~N}^{-1}$, respectively (Table 6). The spatial distribution of annual losses through volatilization, leaching, and denitrification and uptake of $\mathrm{N}$ in the rice-wheat systems of the IGP is shown in Fig. 4. Loss of $\mathrm{N}$ from volatilization was larger in Punjab and West Bengal because of a larger amount of $\mathrm{N}$ use through fertilizer and manure and also because of higher soil $\mathrm{pH}$. A larger amount of $\mathrm{NO}_{3}{ }^{-}$ leaching was simulated in the lower transects because of higher rainfall. Where the upper transect receives only $650 \mathrm{~mm}$ of rainfall per annum, the lower transect receives $>2.5$ times (Ladha et al., 2003). Total loss of $\mathrm{N}$ was 16 to $62 \mathrm{~kg} \mathrm{~N} \mathrm{ha}^{-1}$ in the various states of the IGP. Average $\mathrm{N}$ loss was $30 \mathrm{~kg} \mathrm{~N}^{-1}$ with average fertilizer application of $98 \mathrm{~kg} \mathrm{~N} \mathrm{ha}^{-1}$. Thus $\sim 30.4 \%$ of $\mathrm{N}$ applied through fertilizer and manure was lost from the system. Volatilization, leaching, and denitrification accounted for 15,10 , and $5 \mathrm{~kg} \mathrm{ha}^{-1}$ loss of $\mathrm{N}$, respectively. The simulated balance of $\mathrm{N}$ was negative in all the states. The largest depletion of $\mathrm{N}$ was estimated in Bihar $\left(71 \mathrm{~kg} \mathrm{~N} \mathrm{ha}^{-1}\right)$, followed by Uttar Pradesh (58 kg N ha ${ }^{-1}$ ), Haryana (45 kg N ha $\left.{ }^{-1}\right)$, and Punjab

\begin{tabular}{ccccc}
\hline Legend & $\begin{array}{c}\mathrm{NH}_{3} \\
\text { volatilization, } \\
\mathrm{kg} \mathrm{N} \mathrm{ha}^{-1}\end{array}$ & $\begin{array}{c}\mathrm{NO}_{3} \text { leaching, } \\
\mathrm{kg} \mathrm{N} \mathrm{ha}^{-1}\end{array}$ & $\begin{array}{c}\text { Denitrification, } \\
\mathrm{kg} \mathrm{N} \mathrm{ha}^{-1}\end{array}$ & $\begin{array}{c}\text { Uptake, } \\
\mathrm{kg} \mathrm{N} \mathrm{ha}^{-1}\end{array}$ \\
\hline$<5$ & $<5$ & $<3$ & $<150$ \\
$5-10$ & $5-10$ & $3-6$ & $150-175$ \\
$10-15$ & $10-15$ & $6-9$ & $175-200$ \\
$>15$ & $>15$ & $>9$ & $>200$
\end{tabular}
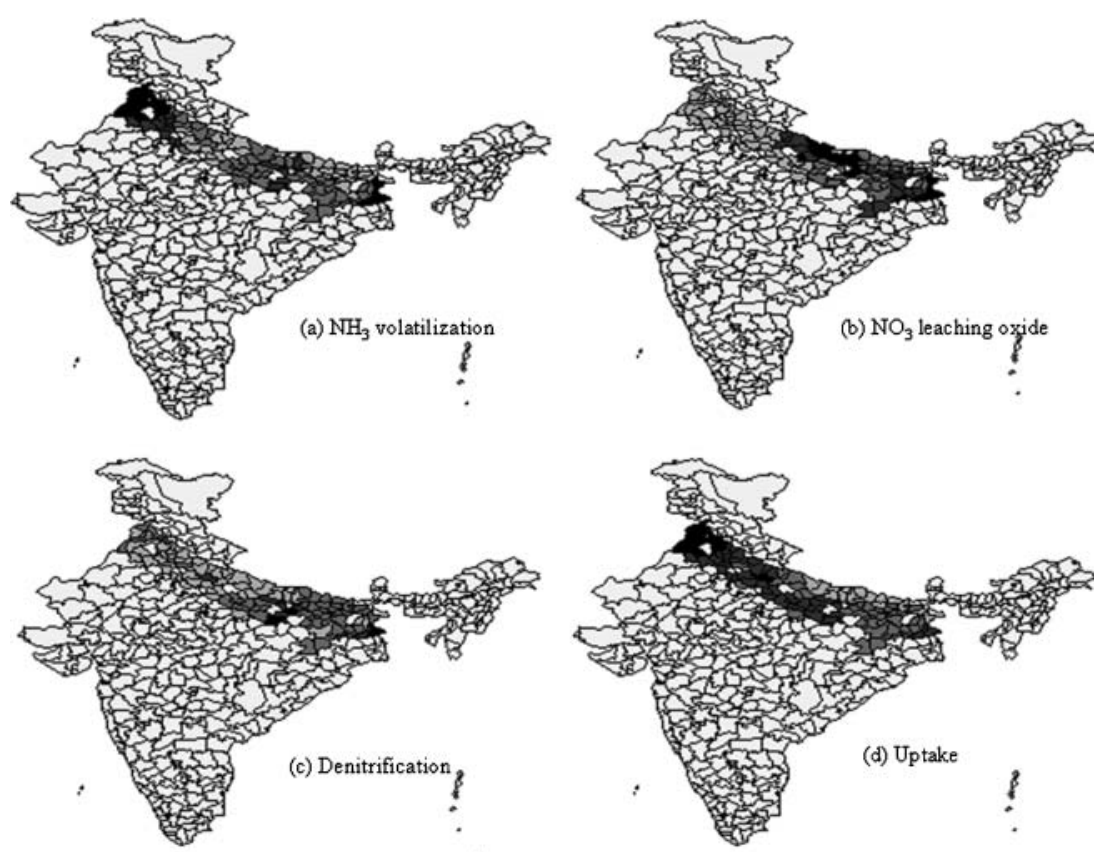

Fig. 4. Annual losses through (a) $\mathrm{NH}_{3}$ volatilization, (b) $\mathrm{NO}_{3}$ leaching, (c) denitrification, and (d) uptake of $\mathrm{N}$ in the rice-wheat systems of the IndoGangetic Plain. 
(22 $\mathrm{kg} \mathrm{N} \mathrm{ha}^{-1}$ ), and the smallest was in West Bengal $\left(19 \mathrm{~kg} \mathrm{~N} \mathrm{ha}^{-1}\right)$. It has been observed that, in most of the rice-wheat long-term experiments in the IGP, the soil organic matter content has declined with time and there is a corresponding yield decline of rice and wheat under recommended NPK treatments (Duxbury et al., 2000; Yadav et al., 2000). In the major rice-wheat regions of northwestern India, the SOC has decreased from $0.5 \%$ in the 1960 s to $0.2 \%$ at present (Sinha et al., 1998, p. 89). This is equivalent to a loss of $3000 \mathrm{~kg} \mathrm{~N} \mathrm{ha}^{-1}$ from the entire soil profile $(120 \mathrm{~cm})$ during a period of 25 to $30 \mathrm{yr}$. A similar decline in organic $\mathrm{C}$ was evidenced in the Pakistan's Punjab (Ali and Byerlee, 2000). During 1971 to 1974 , SOC was $1.02 \%$ and decreased to $0.59 \%$ in 1985 to 1994 , indicating a loss of $4000 \mathrm{~kg} \mathrm{~N} \mathrm{ha}^{-1}$ from the soil profile during the period of $15 \mathrm{yr}$. In our simulation, the average loss was $39 \mathrm{~kg} \mathrm{~N} \mathrm{ha}^{-1} \mathrm{yr}^{-1}$ (Table 6). The loss was high in Uttar Pradesh and Bihar. In these states, flood and runoff contribute some amount of $\mathrm{N}$ annually. But quantification of this contribution is beyond the scope of the model.

Amounts of $\mathrm{N}$ added in the rice-wheat system of the entire IGP through fertilizer, manure, and fixation (which includes $\mathrm{N}$ inputs through atmospheric deposition, biological fixation, and irrigation) were estimated to be 752000,167000 , and $243000 \mathrm{t}$, respectively (Table 7). A similar amount of $\mathrm{N}$ input through fertilizer and manure has been reported by the Fertilizer Association of India (2003). Total N output was $1.515 \mathrm{Mt}$, out of which plant uptake accounted for $1.333 \mathrm{Mt}$. Losses of $\mathrm{N}$ were estimated to be $182000 \mathrm{t}$. Ammonia volatilization, leaching, and denitrification accounted for 46,38 , and $16 \%$ of the total loss, respectively. About $20 \%$ of $\mathrm{N}$ applied through fertilizer and manure was lost from the system.

The relative proportions of different inputs and outputs in different states are presented in Table 7, which shows that fertilizer was the major input and plant uptake the major output of N. Uttar Pradesh accounted for 38 and $40 \%$, followed by Punjab, which accounted for 34 and $28 \%$ of total inputs and outputs, respectively. The other three states (Bihar, Haryana, and West Bengal) together accounted for 28 and $31 \%$ of total

Table 7. Simulated total annual inputs, outputs, and balances of $\mathbf{N}$ in the rice-wheat systems for different states in the IndoGangetic Plain using the current farmers' practice.

\begin{tabular}{|c|c|c|c|c|c|c|}
\hline Parameter & Punjab & Haryana & $\begin{array}{c}\text { Uttar } \\
\text { Pradesh }\end{array}$ & Bihar & $\begin{array}{c}\text { West } \\
\text { Bengal }\end{array}$ & Tot \\
\hline & & & $-G g N$ yr & & & \\
\hline \multicolumn{7}{|l|}{ Input } \\
\hline Fertilizer & 243 & 88 & 301 & 105 & 15 & \\
\hline Manure & 88 & 16 & 33 & 11 & 19 & 1 \\
\hline Fixation $\dagger$ & 62 & 26 & 103 & 46 & 6 & 2 \\
\hline Total inp & 393 & 130 & 437 & 162 & 40 & 11 \\
\hline \multicolumn{7}{|l|}{ Output } \\
\hline Uptake & 378 & 155 & 532 & 235 & 32 & 13 \\
\hline Volatilization & 36 & 9 & 25 & 7 & 7 & \\
\hline Leach & 7 & 1 & 41 & 15 & 4 & \\
\hline Denitrification & 6 & 2 & 13 & 7 & 2 & \\
\hline Total output & 428 & 167 & 610 & 264 & 45 & 15 \\
\hline Balance & -35 & -37 & -174 & -102 & -5 & -3 \\
\hline
\end{tabular}

$\dagger$ Fixation includes $\mathbf{N}$ inputs through atmospheric deposition, biological fixation, and irrigation. inputs and outputs, respectively. All the states had a negative $\mathrm{N}$ balance, ranging from $5000 \mathrm{Mg}$ in West Bengal to $174000 \mathrm{Mg}$ in Uttar Pradesh. The largest negative balance in Uttar Pradesh was due to a large N output relative to inputs and a large geographic area under the rice-wheat system in this state.

\section{CONCLUSIONS}

The DNDC model was generally able to capture the major effects of $\mathrm{N}$ and water on rice and wheat crop performance and balances of $\mathrm{N}$ in the rice-wheat systems of the IGP. The study showed that $\sim 30.4 \%$ of applied $\mathrm{N}$ was lost from the system and $\mathrm{NH}_{3}$ volatilization was the major loss mechanism, followed by leaching and denitrification. The simulated balance of $\mathrm{N}$ was negative in all the states. This shows the vulnerability of the system and calls for improved $\mathrm{N}$ management to stop the depletion of soil $\mathrm{N}$. This is particularly true for the states of Bihar and Uttar Pradesh, where the depletion of soil $\mathrm{N}$ is the largest and immediate attention needs to be paid to minimize this depletion. The application of a higher amount of chemical N, substitution of a part of chemical $\mathrm{N}$ by organic $\mathrm{N}$, and use of better management techniques to increase $\mathrm{N}$ use efficiency have been found to reduce the depletion and improve soil $\mathrm{N}$ status; however, higher fertilizer $\mathrm{N}$ use leads to more losses of $\mathrm{N}$, which may cause environmental pollution. New tools for fertilizer management are therefore needed to reconcile the legitimate aims of improving $\mathrm{N}$ management and reducing losses and optimizing $\mathrm{N}$ application (Ladha et al., 2005). The analysis suggests that models such as the DNDC could be applied for studying N-related issues in the rice-wheat cropping systems of India and would be very useful to accelerate the application of available knowledge at field, farm, and regional levels for quantifying $\mathrm{N}$ losses and optimizing $\mathrm{N}$ management. Planning and agricultural extension personnel can use this tool for optimizing fertilizer availability and distribution in the various states, while the farmers can use it for improved fertilizer management. The model can also be used as a regulatory tool to make projections of future outcomes of fertilizer management scenarios with respect to key environmental areas such as $\mathrm{NO}_{3}$ leaching and environmental pollution.

\section{ACKNOWLEDGMENTS}

We acknowledge the International Atomic Energy Agency for supporting this study; H. Pathak is thankful to the Alexander von Humboldt Foundation, Germany, for providing a fellowship and Institut fur Meteorologie und Klimaforschung, Garmisch-Partenkirchen, Germany, for providing facilities to carry out the work; C. Li's study was supported by the NASA Terrestrial Ecology Program through project TE/02-0018.

\section{REFERENCES}

Aggarwal, P.K., N. Kalra, S. Chander, and H. Pathak. 2006. InfoCrop: A dynamic simulation model for the assessment of crop yields, losses due to pests, and environmental impact of agro-ecosystems in tropical environments. I. Model description. Agric. Syst. 89(1):1-25. Ali, M., and D. Byerlee. 2000. Productivity growth and resource deg- 
radation in Pakistan's Punjab: A decomposition analysis. Policy Res. Working Pap. 2480. World Bank, Washington, DC.

Ashby, J.A., W.B. Bowden, and P.S. Murdoch. 1998. Controls on denitrification in riparian soils in headwater catchments of a hardwood forest in the Catskill Mountains, USA. Soil Biol. Biochem. 30:853-864.

Aulakh, M.S., and Bijay-Singh. 1997. Nitrogen losses and fertilizer N use efficiency in irrigated porous soils. Nutr. Cycl. Agroecosyst. 7:1-16.

Aulakh, M.S., J.W. Doran, and A.R. Mosier. 1992. Soil denitrificationsignificance, measurement, and effects of management. Adv. Soil Sci. 18:2-42.

Aulakh, M.S., T.S. Khera, J.W. Doran, and K.F. Bronson. 2001. Denitrification, $\mathrm{N}_{2} \mathrm{O}$ and $\mathrm{CO}_{2}$ fluxes in rice-wheat cropping system as affected by crop residues, fertilizer $\mathrm{N}$ and legume green manure. Biol. Fertil. Soils 34:375-389.

Banerjee, B., H. Pathak, and P.K. Aggarwal. 2002. Effects of dicyandiamide, farmyard manure and irrigation on ammonia volatilization from an alluvial soil in rice (Oryza sativa L.)-whea (Triticum aestivum L.) cropping system. Biol. Fertil. Soils 36:207-214.

Bhandari, A.L., J.K. Ladha, H. Pathak, A.T. Padre, D. Dawe, and R.K. Gupta. 2002. Trends of yield and soil nutrient status in a long-term rice-wheat experiment in Indo-Gangetic Plains of India. Soil Sci. Soc. Am. J. 66:162-170.

Bijay-Singh, P.R. Gajri, J. Timsina, Yadvinder-Singh, and S.S. Dhillon. 2002. Some issues on water and nitrogen dynamics in rice-whea sequences on flats and beds in the Indo-Gangetic Plains. p. 1-15. In E. Humphreys and J. Timsina (ed.) Modelling irrigated cropping systems, with special attention to rice-wheat sequences and raised bed planting. CSIRO Land and Water Tech. Rep. 25/02. Proc. Workshop CSIRO, Griffith, NSW, Australia. 25-28 Feb. 2002. CSIRO Land and Water, Griffith, NSW.

Brown, L., B. Syed, S.C. Jarvis, R.W. Sneath, V.R. Phillips, K.W.T. Goulding, and C. Li. 2002. Development and application of a mechanistic model to estimate emission of nitrous oxide from UK agriculture. Atmos. Environ. 36:917-928.

Buresh, R.J., T. Woodhead, K.D. Shepherd, E. Flordelis, and R.C. Cabangon. 1989. Nitrate accumulation and loss in a mung beanlowland rice cropping system. Soil Sci. Soc. Am. J. 53:477-482.

Butterbach-Bahl, K., M. Kesik, P. Miehle, H. Papen, and C. Li. 2004. Quantifying the regional source strength of N-trace gases across agricultural and forest ecosystems with process based models. Plant Soil 260:311-329.

Cai, Z., T. Sawamoto, C. Li, G. Kang, J. Boonjawat, A.R. Mosier, R. Wassmann, and H. Tsuruta. 2003. Field validation of the DNDC model for greenhouse gas emissions in East Asian cropping systems. Global Biogeochem. Cycles 17(4):1107 doi:10.1029/2003GB002046.

Dawe, D., A. Dobermann, J.K. Ladha, R.L. Yadav, B. Lin, R.K. Gupta, P. Lal, G. Panaullah, O. Sariam, Y. Singh, A. Swarup, and O.X Zhen. 2003. Do organic amendments improve yield trends and profitability in intensive rice systems? Field Crops Res. 83:191-213

Dobermann, A., and T. Fairhurst. 2000. Rice: Nutrient disorders and nutrient Management. IRRI, Manila, the Philippines.

Duxbury, J.M., I.P. Abrol, R.K. Gupta, and K.F. Bronson. 2000. Analysis of long-term soil fertility experiments with rice-wheat rotations in South Asia. p. 7-22. In I.P. Abrol et al. (ed.) Longterm soil fertility experiments with rice-wheat rotations in South Asia. Rice-Wheat Consortium Pap. Ser. no. 6. Rice-Wheat Consortium for the Indo-Gangetic Plains, New Delhi, India.

Fertilizer Association of India. 2003. Fertilizer statistics (2002-2003). FAI, New Delhi, India.

George, T., J.K. Ladha, B.J. Buresh, and D.P. Garrity. 1992. Managing native and legume fixed $\mathrm{N}$ in lowland rice based cropping systems. Plant Soil 141:69-91.

Katyal, J.C., Bijay-Singh, P.L.G. Vlek, and R.J. Buresh. 1987. Efficient $\mathrm{N}$ use as affected by urea application and irrigation sequence. Soil Sci. Soc. Am. J. 51:366-370.

Katyal, J.C., Bijay-Singh, P.L.G. Vlek, and E.T. Craswell. 1985. Fate and efficiency of $\mathrm{N}$ fertilizers applied to wetland rice. II Punjab, India. Fert. Res. 6:279-290.

Ladha, J.K., H. Pathak, T.J. Krupnik, J. Six, and C. van Kessel. 2005. Efficiency of fertilizer nitrogen in cereal production: Retrospect and prospects. Adv. Agron. 87:85-156.

Ladha, J.K., D. Dawe, H. Pathak, A.T. Padre, R.L. Yadav, Bijay-Singh, Yadvinder Singh, Y. Singh, P. Singh, A.L. Kundu, R. Sakal, N. Ram, A.P. Regmi, S.K. Gami, A.L. Bhandari, R. Amin, C.R. Yadav, S.
Bhattarai, S. Das, H.P. Aggarwal, R.K. Gupta, and P.R. Hobbs. 2003. How extensive are yield declines in long-term rice-wheat experiments in Asia? Field Crops Res. 81:159-180.

Li, C. 2000. Modeling trace gas emissions from agricultural ecosystems. Nutr. Cycling Agroecosyst. 58:259-276.

Li, C., S. Frolking, G.J. Crocker, P.R. Grace, J. Klir, M. Korcdhens, and P.R. Poulton. 1997. Simulating trends in soil organic carbon in longterm experiments using the DNDC model. Geoderma 81:45-60.

Li, C., S. Frolking, and T.A. Frolking. 1992. A model of nitrous oxide evolution from soil driven by rainfall events: 1 . Model structure and sensitivity. J. Geophys. Res. 97:9759-9776.

Li, C., A.R. Mosier, R. Wassmann, Z. Cai, X. Zheng, Y. Huang, H. Tsuruta, J. Boonjawat, and R.S. Lantin. 2004. Modeling greenhouse gas emissions from rice-based production systems: Sensitivity and upscaling. Global Biogeochem. Cycles 18:1-19.

Li, C., Y.H. Zhuang, M.Q. Cao, P.M. Crill, Z.H. Dai, S. Frolking, B. Moore, W. Salas, W.Z. Song, and X.K. Wang. 2001. Comparing a national inventory of $\mathrm{N}_{2} \mathrm{O}$ emissions from arable lands in China developed with a process-based agro-ecosystem model to the IPCC methodology. Nutr. Cycling Agroecosyst. 60:159-175.

Martin, R.E., M.C. Scholes, A.R. Mosier, D.S. Pjima, E.A. Holland, and W.J. Parton. 1998. Controls on annual emissions of nitric oxide from soils of the Colorado shortgrass steppe. Global Biogeochem. Cycles 12:81-91.

Ministry of Agriculture and Cooperation. 2000. Costs of principal crops in India. Ministry of Agriculture and Cooperation, Govt. of India, New Delhi.

National Bureau of Soil Survey and Land Use Planning. 1998. Benchmark soils of India. NBSS and LUP, Nagpur, India.

Parashar, D.C., U.C. Kulshreshtha, and C. Sharma. 1998. Anthropogenic emissions of $\mathrm{NO}_{x}, \mathrm{NH}_{3}$ and $\mathrm{N}_{2} \mathrm{O}$ in India. Nutr. Cycling Agroecosyst. 52:255-259.

Parton, W.J. 1996. The CENTURY model. p. 283-293. In D.S. Powlson et al. (ed.) Evaluation of soil organic matter models using existing long-term datasets. NATO ASI Ser. I, no. 38.

Pathak, H., A. Bhatia, Shiv Prasad, M.C. Jain, S. Kumar, S. Singh, and U. Kumar. 2002. Emission of nitrous oxide from soil in rice-wheat systems of Indo-Gangetic Plains of India. Environ. Monit. Assess 77:163-178.

Pathak, H., J.K. Ladha, P.K. Aggarwal, S. Peng, S. Das, Y. Singh, BijaySingh, S.K. Kamra, B. Mishra, A.S.R.A.S. Sastri, H.P. Aggarwal, D.K. Das, and R.K. Gupta. 2003a. Climatic potential and on-farm yield trends of rice and wheat in the Indo-Gangetic plains. Field Crops Res. 80:223-234

Pathak, H., C.S. Li, and R. Wassmann. 2005. Greenhouse gas emissions from Indian rice fields: Calibration and upscaling using the DNDC model. Biogeosciences 2:113-123.

Pathak, H., S. Prasad, A. Bhatia, S. Singh, S. Kumar, J. Singh, and M.C. Jain. 2003b. Methane emission from rice-wheat cropping system of India in relation to irrigation, farmyard manure and dicyandiamide application. Agric. Ecosyst. Environ. 97:309-316.

Pathak, H., J. Timsina, E. Humphreys, D.C. Godwin, Bijay-Singh, A.K Shukla, U. Singh, and R.B. Matthews. 2004. Simulation of rice crop performance and water and $\mathrm{N}$ dynamics, and methane emissions for rice in northwest India using CERES Rice model. CSIRO Land and Water Tech. Rep. 23/04. CSIRO Land and Water, Griffith, NSW, Australia.

Priestly, C.H.B., and R.J. Taylor. 1972. On the assessment of surface heat flux and evaporation using large scale parameters. Monit. Weather Rev. 100:81-92.

Regmi, A.P., J.K. Ladha, H. Pathak, E. Pasuquin, D. Dawe, P.R Hobbs, D. Joshy, S.L. Maskey, and S.P. Pandey. 2002. Analyses of yield and soil fertility trends in a 20-year rice-rice-wheat experiment in Nepal. Soil Sci. Soc. Am. J. 66:857-867.

Ritchie, J.T., D.C. Godwin, and S. Otter-Nache. 1988. CERES-Wheat: A simulation model of wheat growth and development. Texas A\&M Univ. Press, College Station.

Ritchie, J.T., U. Singh, D.C. Godwin, W.T. Bowen, P.W. Wilkens, B. Baer, G. Hoogenboom, and L.A. Hunt. 1998. GENERIC-CERES V3.5. Int. Fert. Dev. Ctr., Muscle Shoals. AL.

Sachdev, M.S., P. Sachdev, and D.L. Deb. 2000. Fate of fertilizer on irrigated wheat and its pollution potential. p. 129-142. In Optimizing nitrogen fertilizer application to irrigated wheat. IAEA-TECDOC1164. IAEA, Vienna. 
Saggar, S., R.M. Andrew, K.R. Tate, N.J. Rodda, C.B. Hedley, and J.A. Townsend. 2004. Modelling nitrous oxide emissions from New Zealand dairy grazed pastures. Nutr. Cycling Agroecosyst. 68:243-255.

Shrestha, R.K., and J.K. Ladha. 2002. Nitrate pollution in groundwater and strategies to reduce pollution. Water Sci. Technol. 45: 29-35.

Shukla, A.K., J.K. Ladha, V.K. Singh, B.S. Dwivedi, R.K. Gupta, S.K. Sharma, V. Balasubramanian, Y. Singh, H. Pathak, P.S. Pandey, A.T. Padre, and R.L. Yadav. 2004. Calibrating the leaf color chart for nitrogen management in different genotypes of rice and wheat in a systems perspective. Agron. J. 96:1606-1621.

Sinha, S.K., G.B. Singh, and M. Rai. 1998. Decline in crop productivity in Haryana and Punjab: Myth or reality? Indian Council of Agric. Res., New Delhi.

Smith, W.N., R.L. Desjardins, B. Grant, C. Li, R. Lemke, P. Rochette, M.D. Corre, and D. Pennock. 2002. Testing the DNDC model using $\mathrm{N}_{2} \mathrm{O}$ emissions at two experimental sites in Canada. Can. J. Soil Sci. 82:365-374.

Smith, W.N., B. Grant, R.L. Desjardins, R. Lemke, and C. Li. 2004. Estimates of the interannual variations of $\mathrm{N}_{2} \mathrm{O}$ emissions from agricultural soils in Canada. Nutr. Cycling Agroecosyst. 68: $37-45$.

Srivastava, P.C., and T.A. Singh. 1996. Nitrogen in soils and transformation of fertilizer nitrogen. In Nitrogen Research and Crop Production (ed.) HLS Tandon, FDCO, New Delhi, p. 14-31.
Stanford, G., S. Dzienia, and R.A. VanderPol. 1975. Effect of temperature on denitrification rate in soils. Soil Sci. Soc. Am. Proc. 39:867-870.

Stevens, R.J., R.J. Laughlin, and J.P. Malone. 1998. Soil pH affects reducing nitrate to nitrous oxide and di-nitrogen. Soil Biol. Biochem. 30:1119-1126.

Stumm, W., and J.J. Morgan. 1981. Aquatic chemistry: An introduction emphasizing chemical equilibria in natural waters. 2nd ed. John Wiley \& Sons, New York.

Sutton, M.A., C.E.R. Pitcairn, and D. Fowler. 1993. The exchange of ammonia between the atmosphere and plant communities. Adv. Ecol. Res. 24:301-393.

Thiyagarajan, T.M., P. Stalin, A. Dobermann, K.G. Cassman, and H.F.M. Ten Berge. 1997. Soil N supply and plant N uptake by irrigated rice in Tamil Nadu. Field Crops Res. 51:55-64.

Velayutham, M., and T. Bhattacharya. 2000. Soil resource management. p. 1-135. In J.S. P. Yadav and G.B. Singh (ed.) Natural resource management for agricultural production in India. Int. Conf. on managing natural resources for sustainable agricultural production in the 21st century, New Delhi. 14-18 Feb. 2000. New Delhi, India.

Yadav, R.L., B.S. Dwivedi, and P.S. Pandey. 2000. Rice-wheat cropping system: Assessment of sustainability under green manuring and chemical fertilizer inputs. Field Crops Res. 65:15-30.

Yadav, R.L., and A.V.M. Subba Rao. 2001. Atlas of cropping systems in India. PDCSR Bull. no. 2001-02. Project Directorate for Cropping Systems Res., Modipuram, Meerut, India. 